\title{
Library Review
}

Self-other agreement for improving communication in libraries and information services

loannis C. Drivas Damianos P. Sakas Georgios A. Giannakopoulos

\section{Article information:}

To cite this document:

loannis C. Drivas Damianos P. Sakas Georgios A. Giannakopoulos , (2016),"Self-other agreement for improving communication in libraries and information services", Library Review, Vol. 65 Iss 3 pp. 206 223

Permanent link to this document:

http://dx.doi.org/10.1108/LR-06-2015-0064

Downloaded on: 04 J uly 2016, At: 23:48 (PT)

References: this document contains references to 54 other documents.

To copy this document: permissions@emeraldinsight.com

The fulltext of this document has been downloaded 154 times since 2016*

\section{Users who downloaded this article also downloaded:}

(2016),"A formal definition of Big Data based on its essential features", Library Review, Vol. 65 Iss 3 pp. 122-135 http://dx.doi.org/10.1108/LR-06-2015-0061

(2016),"Integration of institutional repositories and e-learning platforms for supporting disabled students in the higher education context", Library Review, Vol. 65 Iss 3 pp. 136-159 http:// dx.doi.org/10.1108/LR-08-2015-0088

(2016),"Modeling the development of the online conference's services", Library Review, Vol. 65 Iss 3 pp. 160-184 http://dx.doi.org/10.1108/LR-06-2015-0063

Access to this document was granted through an Emerald subscription provided by emeraldsrm: 413556 []

\section{For Authors}

If you would like to write for this, or any other Emerald publication, then please use our Emerald for Authors service information about how to choose which publication to write for and submission guidelines are available for all. Please visit www. emeraldinsight.com/ authors for more information.

\section{About Emerald www.emeraldinsight.com}

Emerald is a global publisher linking research and practice to the benefit of society. The company manages a portfolio of more than 290 journals and over 2,350 books and book series volumes, as well as providing an extensive range of online products and additional customer resources and services.

Emerald is both COUNTER 4 and TRANSFER compliant. The organization is a partner of the Committee on Publication Ethics (COPE) and also works with Portico and the LOCKSS initiative for digital archive preservation.

*Related content and download information correct at time of download. 
LR

65,3

206

\begin{abstract}
Purpose - This paper aims to examine the Self-Other Agreement between leaders and employees in the sector of Libraries and Information Services (LIS) to construct a sustainable and strategic communicational process among library directors and staff.

Design/methodology/approach - A sample of 135 leaders-employees of 17 organisations of LIS in more than five countries answered on a quantitative methodological research instrument in a multiplicity of variables. Statistical analysis of independent samples $t$-test was used to testify our research hypotheses.

Findings - Results indicated that there is a difference in means between the two independent samples (leaders-employees). There are library leaders who rate themselves quite high, and there are employees who rate their leaders with lower evaluations.

Research limitations/implications - This research extends and improves the matter of Self-Other Agreement in the sector of LIS through the collection of data that indicated a possible gap of communication and trustworthiness between leaders and employees.

Practical implications - Regardless of the difference or the consensus of ratings among leaders and employees, the results of this research could be served as a stimulus plus as a starting point for library leaders by correcting or developing relations of communication and trustworthiness between them and their followers.

Originality/value - Self-Other Agreement is one of the major factors that positively or negatively affect the overall operation of the organization in the way a leader could perceive the additional feedback. In the sector of LIS, the study of Self-Other Agreement is a rich and unexplored research area which deserves further analysis.
\end{abstract}

Keywords Library management, Transformational leadership, Information science, 


\section{Introduction}

For a library and information service (LIS) to really fulfil its mission, the library leader must not only be doing things right but also be doing the right things (Fitsimmons, 2007). The communication and the coordination between library leader and staff constitute one of the main key factors to establish a sustainable environment for effective provision of services to library clients. However, the quality of communication among library directors and employees must be evaluated regardless of the leadership styles that they are implemented. The leadership research topic relies heavily on employees' ratings on their leader's behaviour to evaluate the effectiveness of various leadership theories and styles (Hansbrough et al., 2014). In many cases, leaders rate themselves high on the way they lead their team. In other cases, leaders believe that each of their decisions is positive for the overall good for the entire group. Nevertheless, employees may have a different opinion about their leaders. It is possible for a group to complete all the tasks in the workplace, but to be particularly dissatisfied, stressed or exhausted because of the methods and decisions applied by the leader.

This research raised in the first phase the necessity of the adoption of leadership behaviours that promote trust and communication between leaders and employees in the sector of LIS. In the second phase, an attempt will be carried out to focus on the interpersonal perception of library leaders on how they rate themselves or how employees rate their leaders. The comparison of these two factors (employees-leaders) gives the advantage of searching for and developing a theoretical approach which is focused on the high performance of human resources through a two-way communication between leader and team members. In response to this claim, library leaders are using management techniques that rely less on "command and control" protocols and more on management practices that encourage staff communication, collaboration and consensus decision-making (Castiglione, 2006).

\section{The necessity of leader-members communication}

The library leader holds a primary role during a project to improve the service quality of the organisation. The leader is the person who encourages the members of the group, solves problems and obstacles and very often is at the negotiating table, seeking the best possible result. The value which a leader adds during a project is unique; no other method or practice adds the same value (Stephenson, 2008).

Managers have to face many new challenges including developments in communications and information technology, increasing competition due to globalisation, the importance of the strategic management perspective, demands for transparency, the emergence of sustainability and the ever-increasing importance of human resources management (Trivellas and Reklitis, 2014). On this point, it is recognised that human resources constitute a critical factor for determining the success of the service exchange and customer satisfaction within organisations (Broady-Preston and Steel, 2002a, 2002b).

As it is difficult for leaders to identify, interpret and deal with challenges on their own, employees are recognised as an invaluable source, having the opportunity to submit comments and proposals for dealing with and resolving the upcoming problems (Detert and Burris, 2007). Motivating employees within an appropriate leadership style to submit their thoughts to their leaders can be operated in a most constructive manner within the whole group. Additionally, Muhammad and Khalid's (2010) study brought to
Communication

in libraries and information services

207 
LR

65,3

208

light the influence of leadership styles, organisational culture and commitment of library professionals and also the combination of styles and behaviours to manage a rapidly changing environment such as LIS.

The plurality of leadership styles and their adoption depends on the problem and comes into direct relation with the level of communication skills held by the leader. Furthermore, it is quite possible that a success of a style does not depend only on the style and the advantages of it but also on the timing that will be used. Previous research has highlighted that poor communication skills is one of the primary reasons for the degradation of a group's behaviour, which starts from poor performance and the reduction of the morale of the workforce and results in low productivity (Alexander et al., 1989; Hofmann and Morgeson, 1999). Communication management and organisational "resources" can lead an organisation to success and employees to their professional development (Markaki et al., 2013). For Hallahan et al. (2012), the purpose of communication management is to facilitate the orderly operations of the organisation and also to promote understanding of an organisation's mission, vision and goals. Hence, communication skills constitute a particularly important attribute for leaders in the LIS profession to disseminate the organisation's mission, vision and goals. Therefore, it is quite possible that a leader's poor communication skills result in the difficulty of adopting different leadership styles or disseminating the vision of an organisation among team members.

Various studies describe the leader's skills and characteristics in the LIS sector (Ammons-Stephens et al., 2009; Fitsimmons, 2008; Kreitz, 2009). More particularly, Ammons-Stephens et al. (2009) stated the importance of several communication skills that a leader must have, such as active listening or the creation of an environment that encourages active communication. Fitsimmons (2008) referred to the characteristic of collaboration in a working environment among leaders and staff and the positive personality of a library leader. Additionally, the research of Kreitz (2009) indicates that the articulation of direction of the organisation and the clear vision of the leader constitute some of the main key points regarding the characteristics of library directors. All the above findings indicated the vital importance of strategic communication among leaders and employees, not only in the LIS profession but also within the wider entrepreneurial community which acts in an overall collaborative environment that supports communication among individuals of each organisation.

\section{Communication improvement and feedback}

A communication model which acts efficiently achieves to extract the equivalent feedback for a library director. A key consideration, and a separate path of development, is to understand how leadership communication drives results and how the latter can be appraised and fed back to the organisation (Markaki et al., 2014; Sakas and Kutsikos, 2014; Sakas et al., 2014). For Dyer (2001), the process of feedback can be used as a tool, which gives a leader an authentic criticism about his relationship (among the team members), whether these relations are active or passive. Employees' personal point of view can be operated as feedback for a leader to evaluate his effectiveness in applied leadership behaviours in the LIS sector.

The aforementioned feedback may come through the adoption of leadership behaviours. For example, low ratings by employees of their leader in a specific leadership style occur as feedback to a leader to improve his overall performance. In this 
study, we analyse the Transformational and Leader Member Exchange leadership behaviours as a method to close the gap between the ratings of employees and self-ratings of leaders. Previous qualitative research with an interview process involving 12 library directors indicated some crucial points for effective communication among the team. More particularly, interviewers pointed out several characteristics of their leadership style in their decision making process. Several factors that were discussed with interviewers were leader's attempt to motivate their team, leader's effort to inspire employees submitting their proposals, leader's motivation to develop employees' skills, employee's participation and contribution in decision-making processes, level of working communication between the leaders and employees and so on. Transformational and Leader-Member Exchange (LMX) behaviours include the majority of the aforementioned interview topics. The level of trust between leader and employee can be developed by applying these two leadership behaviours. A related study by Gao et al. (2011) showed that a result that leader's trustworthiness to his members can substantially contribute to the increment of employees to suggest their proposals. Furthermore, these findings indicated that the strengthening of leader's willingness to promote employees' suggestions will show a contributory benefit when a leader adopts behaviours which encourage and allow employees to participate and to submit their own opinions. The library administrator could adopt Transformational and LMX as leadership behaviours to encourage and enable employees to participate and to submit their own opinions to the upper management levels.

In this study, we try to seek out a possible gap in the communication process between employees and leaders on common variables. This possible communication gap can be operated as a requital feedback for improving communicational level between leaders and library staff. As mentioned earlier, a leader may have the belief that he leads his group ideally, but on the other hand, his members may have a different personal point of view. This conceptual difference can be seen through the evaluation ratings. Specifically, how leaders evaluate themselves in comparison to how their employees evaluate them.

\section{Transformational leadership}

This leadership style has gathered wide research attention. The number of reports and articles on transformational leadership has increased significantly (Antonakis, 2012). For Lowe and Gardner (2001), one-third of the research in general leadership is based on this model. The multi-faceted and multidisciplinary research development of transformational leadership gives a definition which best matches this research. Within the framework of this study, transformational leadership is defined as a process whereby a person engages with others and creates a connection that raises the level of motivation and morality in both leaders and their followers (Northouse, 2013).

Analysing the two axes of the definition, in the first axis, we have the topic of motivational improvement, where we can include the improvement of skills of employees and leaders through various activities such as assistance for continuing educational training. The second axis involves the topic of ethics. The second axis can contain the development of communication between leaders and employees with particular emphasis on increasing the trust and reliability, inspiring both the followers and the leader, respectively. This bilateral relationship between motivation and morality is possible to create a dependency with a positive sign between leader and
Communication in libraries and information services

209 
LR

65,3

210

group members in most of the library's operations. Furthermore, the findings of Kark and Shamir (2002) indicated that transformational leadership has a positive correlation with employees' empowerment in a group. Additionally, according to Castiglione (2006), a transformational library administrator embrace staff members with an opportunity to express themselves and construct a compelling vision of future possibilities for themselves.

The model of transformational leadership on the one hand leads to the development of communication relations between supervisor and employee; on the other hand, it develops the skills and abilities of followers. Transformational leadership could be served as a link between the self-ratings of leaders and ratings of employees. More specifically, the exhibited evaluations of transformational leadership models, linked with behaviours of employees such as extroversion, pleasantness, transparency and awareness (Bono et al., 2012; Felfe and Schyns, 2010).

\section{Leader-member exchange}

LMX refers to the quality of the exchange relationship that exists between employees and their superiors (Graen and Uhl-Bien, 1995). Additionally, transformational leadership is based on a varied research background, and thereby LMX theory aggregates a solid thriving background rather than a stagnant implication, since the mid-1970s. The first approach (Densereau et al., 1975; Graen, 1976) developed a bilateral relationship between leader and employee: those who were in-group and those who were out-group. For Densereau et al. (1975), those who are in-group receive more information, influence, confidence and concerns from their leaders than do the out-group employees. Whereas in-group members do extra things for the leader and the leader does the same for them, followers in the out-group are less compatible with the leader and usually just come to work, do their job and go home (Densereau et al., 1975).

The theories of Graen and Dansereau are older than the current approaches, and, at first glance, it seems to be working as a tool for improving communication and trust between leader and employee. However, this separation (in-group and out-group) is likely to operate as an unintentionally divisive tool between active and passive followers among the library staff. Everyone who has ever worked in an organisation has felt the presence of in-groups and/or out-groups (Northouse, 2013). The leader is the one who will establish a special relationship with all his employees and not with a proportion of them (Graen and Uhl Bien, 1991).

At this point, it is worth noting that to achieve a common special relationship with all employees, the library director must give everyone the opportunity to assume new responsibilities, investing in employees' professional development, creating in this way organisational justice performance and fair treatment for all the employees. According to the findings of Shan et al. (2015), the LMX style and justice in all team members has a positive correlation with job performance in an LIS organisation. A library leader can foster a greater sense of employee worth and teamwork among staff members by providing justice in interpersonal treatment (Burton et al., 2008). While cultivating a positive climate which promotes dialogue, and therefore in the second phase trustworthiness, is more likely to have greater correlations and similarities between employees' ratings and self-ratings of leaders. In this case, both transformational leadership and LMX styles constitute a key management priority for a library 
administrator about the way he communicates, creating a barometer of balance between others' ratings and self-ratings.

\section{Self-Other agreement}

A solid theoretical approach concerning the difference between ratings of leaders and employees, presented by a theory called Self-Other Agreement. Self-Other Agreement can be defined as the degree of agreement-identification between self-ratings of leaders and ratings of others (Atwater et al., 2009; Ostroff et al., 2004; Yammarino and Atwater, 1993). The ratings of others may come from employees or supervisors (Amundsen and Martinsen, 2014) in this way bringing the meaning of feedback. Self-assessment is used for a wide variety of purposes in organisations, including as part of the performance appraisal process, in 360-degree feedback programs (Fleenor et al., 2010).

An effective feedback which comes from self-ratings of leaders and ratings of employees may be affected by certain factors prolonging the gap and the difference between leaders' ratings and employees' ratings. A comprehensive overview of Fleenor et al. (2010) works as a record tool of the factors that affect self-ratings of leaders. Demographic characteristics of leaders (age, education and job relevant experience), personality and other individual characteristics such as self-monitoring, self-esteem, efficacy and locus of control can significantly affect leaders on how they evaluate themselves. These are several factors that may affect self-rating values of library directors and staff. The other side (others' ratings) may be influenced by other factors (Fleenor et al., 2010; Hansbrough et al., 2014). The distance between employees and leaders, and more specifically the distance as to the frequency interaction between leader and employee (Antonakis and Atwater, 2002), plus the experience and performance of the employee, or even the objectives of members, is likely to affect the way in which they rate their supervisor.

The aforementioned factors could affect the harmony among ratings of employees and self-ratings of leaders. In the discussion of the article "Reconsidering the Accuracy of Follower Leadership Ratings" by Hansbrough et al. (2014), there are listed solutions for improving employees' rating accuracy. There are more than five general ideas listed which could help the leader to improve the accuracy of ratings. Hansbrough et al. (2014) referred to solutions which are focused on employees, in solutions which are oriented towards the collection of data with correct measurement tools, as well as the analysis of the data by checking each individual difference which affect the accuracy of ratings.

The above findings are essential stipulations for reducing the difference in ratings; however, the solution to reduce the gap represents a more simple anthropocentric and team-collaborative approach. Considering the library leader as a key factor reducing the gap, we focus our attention in efforts of adopting leadership behaviours which optimise the communication and interaction between leader and employees and, at the same time, improve the trustworthiness between the two sides (self-rater and rater).

The practices and methods contained within the transformational leadership and LMX may strengthen certain levels which are essential for the reduction of the difference in ratings. Using these leadership models at an early stage, it is possible to achieve an improvement of communication between leader and group members. The next step is to increase the trust of both sides, while in the final stage is possible to decrease the difference on self-ratings and others' ratings as well as antedate by a clear collaborative relationship between leader and employee. Therefore, to test the level of
Communication in libraries and information services

211 
LR

65,3

\section{2}

\section{Methodology}

As mentioned earlier, previous qualitative methodological research, with an interview process involving 12 leaders in LIS organisations, identified a research gap regarding the communication process between team members. In this study, a specific number of variables were selected through a general assembly quantitative methodological tool encountered in international literature. The survey's content validity was established via pre-testing process in ten "pre-test" participants to make remarks regarding the items (Chatzoglou et al., 2009).

It was attempted to choose a particular plurality of variables associated with theoretical approaches of transformational leadership and LMX theory in examining whether these variables influence, reduce or increase the difference between self-ratings and others-ratings. Furthermore, several items that evaluate leaders' communication skills were selected to examine the difference in means between employees' ratings and leaders' self-ratings along this axis. The selection of this axis was conducted to identify in the most profound way the overall quality of communication process among leaders and employees in the sector of LIS. The possible differentiation in responses between the two samples is not carried out to compare leaders' and employees' job effectiveness and quality. Besides, these two samples are completely independent from each other with different responsibilities for leaders and employees. This comparison is carried out to examine a possible existing gap in the communication process between the two samples. By the outcome, a potential feedback can be created for the construction of strategic planning for communication within the organisation.

Table I encapsulates the behaviours - theoretical approaches that could reduce the difference between self-ratings and others-ratings, the number of variables corresponding to each of the behaviours and the relevant literature from where the variables come.

\begin{tabular}{lll}
\hline & $\begin{array}{l}\text { No. of variables used to } \\
\text { measure each behaviour }\end{array}$ & Related literature \\
\hline $\begin{array}{l}\text { Transformational } \\
\text { leadership }\end{array}$ & Six variables & Bass (1990), Bass and Avolio (1995) \\
$\begin{array}{l}\text { Leader-member } \\
\text { exchange }\end{array}$ & Six variables & $\begin{array}{l}\text { Collins (2007), Graen and Uhl-Bien } \\
\text { (1995), Scandura } \text { et al. (1986) } \\
\text { skills }\end{array}$ \\
seads communication & Four variables & $\begin{array}{l}\text { Blake and McCanse (1991), LaFasto } \\
\text { and Larson (2001) }\end{array}$
\end{tabular}

Table I.

Variables used for questionnaire construction relationship and communication between leaders and employees, the following

H1. There is a difference in means in variables of transformational leadership, between employees' ratings and leaders' self-ratings.

H2. There is a difference in means in variables of LMX Theory between employees' ratings and leaders' self-ratings.

H3. There is a difference in means in variables associated with Leader's communication skills, between employees' ratings and leaders' self-ratings.

\section{.}


For the collection of data, a questionnaire was constructed which has been divided into three categories. The three categories were transformational leadership, LMX and leader's communication skills. To encapsulate respondents' profiles, we used five demographic items such as gender, age, work experience, level of education and the position of respondent (leader or employee). Further attempt was made for participants to answer as honestly as possible (Podsakoff et al., 2003) in a five-point Likert Scale, minimising the proclivity to respond in a socially desirable way. Moreover, the anonymity and the confidentiality of participants' answers became clear.

The people who were approached to complete the questionnaire numbered 260. A convenience sampling method was purposively used to achieve respondents who were directly associated with the LIS sector, in this way providing as far as possible a representative sample. Additionally, the convenience sampling was used to have a high availability in data gathering. All the respondents come from 17 different LIS organisations: twelve academic libraries and five public libraries from six European countries - Greece, Spain, Italy, Sweden, France and Portugal. Each organisation had different economic and human resources, as well as different organisational structures in relation to the others. A total of 260 people were initially approached, and 227 agreed to participate in this survey. After one reminder, 135 respondents (of 227) completed the questionnaire, with a response rate of 59.47 per cent. The questionnaire was sent to participants via e-mail. Statistical analysis was used as a methodological research instrument to testify the aforementioned hypotheses. Independent samples $t$-test was used as a statistical methodological tool. There are two independent groups (leaders and employees) investigating the opinion-attitude on common variables by defining a significant level Sig. two-tailed $=0.05$.

\section{Results}

The following table is associated with the demographic results, encompassing the respondents' profile (Table II).

Regarding the population of leaders, 60.4 per cent are men while the remaining 39.6 per cent are women. One more remarkable result is the fact that the majority of leaders (69.7 per cent) come from the age category of 36-50 years, while the leaders who are aged more than 50 years amount to 25.9 per cent. It should be noticed that, in the entire population of leaders, 18 per cent hold a doctorate diploma. In this particular research, it is noticed that those who have a $\mathrm{PhD}$ title are not equal to the position of the leaders. Additionally, regarding the level of education, there is a high percentage of respondents with undergraduate degrees (43 per cent) plus a high percentage of respondents with postgraduate studies (31 per cent). As mentioned earlier, the percentage of high educational level may work as an influencing factor that affects the entirety of Self-Other Agreement (Fleenor et al., 2010).

The library leaders' group was associated with a transformational leadership variables volume with a mean of 4,05(SD 0,077). By comparison, the employees group was associated with a numerically smaller transformational leadership (TL) rates volume $M=3.24$ (SD 1.126). To test the first hypothesis regarding the difference in means in variables of transformational leadership, between employees' ratings and leaders' self-ratings, an independent samples $t$-test was performed. As can be seen in Table I, the leaders and employees differ in means of variables associated with transformational leadership. All the variables have $p$-value $<0.05$ significant level
Communication in libraries and information services

213

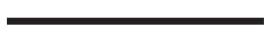




\section{LR \\ 65,3}

\begin{tabular}{llr}
\hline Measure & Demographic items & $(\%)$ \\
\hline Gender & Female & 41.5 \\
Age & Male & 58.5 \\
& $36-50$ & 39 \\
& $26-35$ & 28 \\
Work experience & $18-25$ & 14 \\
& More than 50 & 19 \\
& More than 12 years & 44 \\
Education & 6 to 12 years & 31 \\
& 2 to 5 years & 18 \\
& 0 to 2 years & 7 \\
Position & High school & 14 \\
& Undergraduate studies & 43 \\
& Postgraduate studies & 31 \\
& PhD & 12 \\
& Leaders & 17.4 \\
& Employees & 82.6
\end{tabular}

Table II. Note: Sample size: $N=135$

Respondents' profile Source: Data survey

which means that there is a difference in means between leaders' self-ratings and employees' ratings. However, the first item of transformational leadership questions has a diversified $p$-value $=0.470>0.05$. That means that ratings between leaders and employees in variable "Leader's revelation of thoughts and feelings in his group" do not differ with a high statistical efficiency (Mean difference 0.21). Thus, in H1, there is a difference in means of variables of transformational leadership, between employees' ratings and leaders' self-ratings (Table III).

Progressing to testify the verification of $H 2$, the leaders' group was associated with LMX items volume with a mean of 4.21 (SD 0.78). The employees' group consisted of a different numerically smaller mean of 3.28 (SD 1.16). Independent samples $t$-test was performed to testify the correlation between leaders' self-ratings and employees' ratings. Table II presented the differentiation of means between leaders and employees in LMX variables. Regarding Table II, all the items of LMX have $p$-value $<0.05$ significant level, and that means that there is a difference in means between leaders' self-ratings and employees' ratings. None of the variables of LMX axis have $p$-value $>0.05$. Therefore, testing $H 2$, there is a difference in means of variables related with LMX theory between employees' ratings and leaders' self-ratings (Table IV).

To test the $H 3$ and the possibility of an existence gap between leaders' self-ratings and employees' ratings, a number of variables selected related to leaders' communication skills. In this case, employees' ratings related numerically with a Mean of 3.29 (SD 1.23). Leaders' self-ratings are quite a bit higher with a Mean of 4.20 (SD $0.77)$. The independent samples $t$-test which is used in this situation indicated that there is a statistically significant difference in how leaders evaluate themselves and how employees evaluate their leaders in common variables, just as much as the other two hypotheses. More particularly, none of the variables related to leader's communication skills showed a significant statistical difference between the two independent samples, 


\begin{tabular}{|c|c|c|c|c|c|c|}
\hline Tested variables & $\begin{array}{l}\text { Mean of } \\
\text { leaders }\end{array}$ & $\begin{array}{c}\text { Mean of } \\
\text { employees }\end{array}$ & $\begin{array}{c}\text { Sig. } \\
\text { (two-tailed) }\end{array}$ & $\begin{array}{c}\text { Mean } \\
\text { difference }\end{array}$ & $\mathrm{SD}$ & $\begin{array}{l}\text { Communication } \\
\text { in libraries and }\end{array}$ \\
\hline $\begin{array}{l}\text { Leader's revelation of } \\
\text { thoughts and feelings in } \\
\text { his/her group }\end{array}$ & 3.00 & 2.78 & 0.470 & 0.21 & $\begin{array}{l}\text { Leader: } 1.02 \\
\text { Employee: } 1.13\end{array}$ & services \\
\hline $\begin{array}{l}\text { Care for the development } \\
\text { of employees' potential }\end{array}$ & 4.38 & 3.63 & 0.010 & 0.75 & $\begin{array}{l}\text { Leader: } 0.69 \\
\text { Employee: } 1,14\end{array}$ & 215 \\
\hline $\begin{array}{l}\text { Personal attention to } \\
\text { each group member }\end{array}$ & 4.22 & 3.38 & 0.002 & 0.83 & $\begin{array}{l}\text { Leader: } 0.73 \\
\text { Employee:1.03 }\end{array}$ & \\
\hline $\begin{array}{l}\text { Leader's awareness that } \\
\text { his choices affecting } \\
\text { work of group member }\end{array}$ & 4.27 & 3.34 & 0.000 & 0.93 & $\begin{array}{l}\text { Leader: } 0.66 \\
\text { Employee: } 0.98\end{array}$ & \\
\hline $\begin{array}{l}\text { Provision of vision and } \\
\text { sense of mission from } \\
\text { the leader }\end{array}$ & 4.22 & 3.16 & 0.001 & 1.05 & $\begin{array}{l}\text { Leader: } 0.80 \\
\text { Employee: } 1.19\end{array}$ & \\
\hline $\begin{array}{l}\text { Provides an integrated } \\
\text { plan for the completion } \\
\text { of the project }\end{array}$ & 4.17 & 3.20 & 0.002 & 0.97 & $\begin{array}{l}\text { Leader: } 0.73 \\
\text { Employee: } 1.26\end{array}$ & \\
\hline \multicolumn{6}{|c|}{$\begin{array}{l}\text { Note: } N=135 \text { Significant level }=0.05 \\
\text { Source: Data survey }\end{array}$} & $\begin{array}{r}\text { Table III. } \\
\text { Transformational } \\
\text { leadership variables }\end{array}$ \\
\hline
\end{tabular}

when all the variables related with $p$-value $<0.05$. Eventually, verifying $H 3$, it can be said that there is a difference in the means of variables associated with leaders' communication skills, between employees' ratings and leaders' self-ratings. Variables of leader's communication skills and the results of this axis can be seen in Table V.

An overall difference in means of evaluations among the three axes in the two independent samples, between leaders and employees, can be seen in Figure 1.

\section{Discussion}

To summarise the key findings of this research approach, it can be generally observed that library directors evaluate themselves quite highly in the majority of variables. However, most of the employees evaluated their supervisors with lower ratings. There are the over-estimators: individuals who "think" they are good performers, but others see their performance less favourably - using a popular line from a movie, they are "legends in their own minds" (Yammarino and Atwater, 1997). This phenomenon was also observed in all three different axes (transformational leadership, LMX and leaders' communication skills. Atwater and Yammarino (1997) supported the view that a leader whose self-ratings agree with others' ratings as to their high levels of effectiveness is more likely to be linked to positive individual and organisational outcomes. However, leaders who agree with their subordinates in the low ratings are more likely to have negative impact within the organisation.

In addition, the difference in equality of means in the majority of cases was quite high, in many cases even more than 1.05. The only exception was Variable 1 ( $p$-value $=$ $0.470>0.05$ ) of transformational leadership (leader's revelation of thoughts and feelings in his/her group) where both leaders and employees proceeded to low ratings. 


\begin{tabular}{|c|c|c|c|c|c|}
\hline Tested variables & $\begin{array}{l}\text { Mean of } \\
\text { leaders }\end{array}$ & $\begin{array}{l}\text { Mean of } \\
\text { employees }\end{array}$ & $\begin{array}{c}\text { Sig. } \\
\text { (two-tailed) }\end{array}$ & $\begin{array}{c}\text { Mean } \\
\text { difference }\end{array}$ & $\mathrm{SD}$ \\
\hline $\begin{array}{l}\text { Leader's freedom on how } \\
\text { team members will carry } \\
\text { out their job }\end{array}$ & 4.27 & 3.2 & 0.01 & 1.07 & $\begin{array}{l}\text { Leader: } 0.66 \\
\text { Employee: } 1.19\end{array}$ \\
\hline $\begin{array}{l}\text { Leader's supporting a } \\
\text { decision in case of } \\
\text { absence of the person } \\
\text { who took the decision }\end{array}$ & 4.17 & 3.34 & 0.003 & 0.83 & $\begin{array}{l}\text { Leader: } 0.64 \\
\text { Employee: } 1.14\end{array}$ \\
\hline $\begin{array}{l}\text { Leader's satisfaction } \\
\text { about the task and the } \\
\text { result of }\end{array}$ & 4.05 & 3.12 & 0.004 & 0.93 & $\begin{array}{l}\text { Leader: } 0.87 \\
\text { Employee: } 1.21\end{array}$ \\
\hline $\begin{array}{l}\text { Leader's stability on core } \\
\text { goals independently } \\
\text { from external influences }\end{array}$ & 4.28 & 3.2 & 0.002 & 1.08 & $\begin{array}{l}\text { Leader: } 0.75 \\
\text { Employee: } 1,09\end{array}$ \\
\hline $\begin{array}{l}\text { Leader's possibility to } \\
\text { solve with his power an } \\
\text { upcoming problem }\end{array}$ & 4.24 & 3.16 & 0.001 & 1.08 & $\begin{array}{l}\text { Leader: } 0.80 \\
\text { Employee: } 1.19\end{array}$ \\
\hline $\begin{array}{l}\text { Leader's recognition for } \\
\text { the personal } \\
\text { development of each } \\
\text { team member }\end{array}$ & 4.22 & 3.45 & 0.013 & 0.77 & $\begin{array}{l}\text { Leader: } 0.94 \\
\text { Employee:1.15 }\end{array}$ \\
\hline
\end{tabular}

Table IV.

Leader-member exchange variables
Notes: $N=135$; significant level $=0.05$

Source: Data survey

\begin{tabular}{lccccl}
\hline Tested variables & $\begin{array}{c}\text { Mean of } \\
\text { leaders }\end{array}$ & $\begin{array}{c}\text { Mean of } \\
\text { employees }\end{array}$ & $\begin{array}{c}\text { Sig. } \\
\text { (two-tailed) }\end{array}$ & $\begin{array}{c}\text { Mean } \\
\text { difference }\end{array}$ & SD \\
\hline $\begin{array}{l}\text { Leader help group members } \\
\text { to know each other }\end{array}$ & 3.95 & 3.18 & 0.028 & 0.77 & $\begin{array}{l}\text { Leader: } 0.90 \\
\text { Employee: } 1.32\end{array}$ \\
$\begin{array}{l}\text { Leader's concern for the } \\
\text { psychology of team }\end{array}$ & 4.24 & 3.40 & 0.002 & 0.84 & $\begin{array}{l}\text { Leader: } 0.73 \\
\text { Employee: } 1.11\end{array}$ \\
$\begin{array}{l}\text { Leader's positive response } \\
\text { to the proposals presented }\end{array}$ & 4.36 & 3.54 & 0.011 & 0.82 & $\begin{array}{l}\text { Leader: } 1.30 \\
\text { Employee: } 0.69\end{array}$ \\
$\begin{array}{l}\text { by group members } \\
\text { It is leader's priority to } \\
\text { create a climate that }\end{array}$ & 4.23 & 3.03 & 0.000 & 1.20 & $\begin{array}{l}\text { Leader: } 0.75 \\
\text { Employee: } 1.21\end{array}$
\end{tabular}

Table V.

Leader's communication skills supports communication among the group

Notes: $N=135$; significant level $=0.05$

Source: Data survey 
Due to this difference, the statistical significance in means for this variable ranged quite low M.Diff $=0.21$. Regarding to this variable, it could be assumed that the results reflect the level of communication between leaders and employees. Some employees may have replied with high answers in the Likert scale on this item. However, this could strengthen theories of in-groups and out-groups rather than relations of trust between leaders and employees. At this point, it should be taken into account the findings of Amundsen and Martinsen (2014) mentioned that they are often hard-working individuals who maintain pleasant relationships with their supervisors, and it is important that they be made more aware of their qualities as employees.

There is an additional noteworthy statistical result indicated in this research. Observing the statistically significant level in differentiation of means between the two samples, we can highlight the highest mean difference in leader's communication skills, specifically in Variable 4 "It's leader's priority to create a climate that supports communication among the group" with an M.Diff $=1.20$. On the other side, employees' lowest mean rate is observed in the same variable with a mean of 3.03. Furthermore, the highest statistical mean rate of leaders is observed in TL variables in item "Care for the development of employees' potential" with a mean of 4.38. However, in this common variable, employees' mean rate ranged with a mean of 3.65. Discussing these differences and noteworthy results, it can be said that in this sample, a gap of communication between leaders and employees is recognised. Although library administrators evaluate their overall leadership skills with high rates, the other LIS staff, excluding library managers, evaluate them with a lower means.

To improve managerial processes in LIS, it is quite helpful to consider this study as a solid stepping stone for improving the leadership process in a libraries environment. More particularly, this methodological quantitative research tool and the statistical analysis tests that were performed can be used as a mechanism tool in any organisation related to LIS, to have a preliminary aspect regarding the level and the quality of communication and collaboration between leader and employees. As Broady-Preston and Lobo (2011) state, libraries are still searching for mechanisms which accurately describe their effectiveness. This communicational mechanism could measure the overall effectiveness of collaboration and coordination among group members. In addition, a library administrator can benefit from this study to identify in the most profound way several communication problems which need
Communication in libraries and information services

217

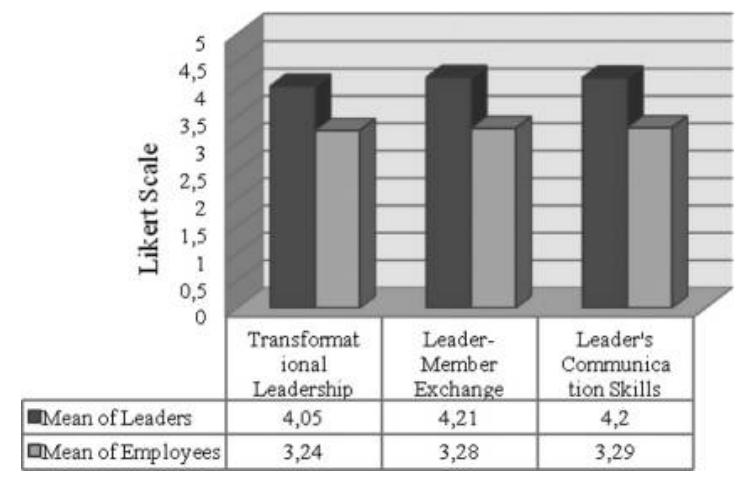

Figure 1. Overall mean of leaders and employees among the three main axes 

stable communication planning process wherein all employees have the opportunity to show and apply their skills, this research can be operated as a starting point for a high level of job satisfaction and fair treatment of group members in a LIS organisational environment. Colleen (2015) states that there is little in the way of formal path-setting in the profession that could guide a librarian interested in becoming a director. This study could also be indicated as a starting information point for a future library leader to create a strategic communication process in an LIS environment.

With regard to the matter of confidence between leaders and employees, if it is not the key, perhaps it is a piece of the main key to reduce the gap between ratings while improving communication and collaboration in an LIS environment. The research findings of Saunders (2015) indicated collaboration among team members of an LIS organisation as the third value of an overall strategic planning process in an academic library. Fleenor et al. (2010) also argues that to facilitate more accurate ratings, organisations should foster environments in which raters have incentives, tools and opportunities to accurately observe and recall ratees' performance. In any case, through this research and the sample of it, it can be demonstrated that a library administrator may have the belief that he leads his group ideally but that the opinions and thoughts of his employees are completely different.

In this case, the matter of feedback works as a starting point to close this gap of difference. More specifically, although the difference of thoughts between leaders and employees is high, this is not a starting point to create group camps that hatch a communication crisis for a team. Instead of this, library leaders can create a milestone for completed and clear feedback, to rectify or to improve those sections which lack attention and might evolve into future problems for the organisation.

The difference among the ratings of leaders and employees could also improve and open the door for the continuing professional development of staff. This thought is indicated in Variable 2 of transformational leadership with a mean of employees of 3.63 and a mean of leaders of 4.38 regarding the care for the development of employees' potential. According to the above findings, all the libraries have processes in place to recruit, train and develop staff (Broady-Preston and Steel, 2002a, 2002b). In addition, many organisations are less than enthusiastic in their support of continuing professional development for their employees, viewing it as a means of benefiting their competitors, rather than themselves (Broady-Preston and Bell, 2001). The difference among the ratings can be served as high quality feedback with a positive sign for leaders as well, as it will help to promote greater attention to the personal needs and the specifications of each team member. Therefore, as a result of this, it will help to create a professional, solid and continuing potential development for the staff as a strategic communication planning process taking place in an LIS organisation.

\section{Future applications and research limitations}

The topic of Self-Other Agreement as well as interpersonal perception is a susceptible, a multidisciplinary and a cross-curricular field of rich research development. In this research project, it was chosen to adopt variables which correspond with leadership behaviours and styles (transformational leadership and LMX). The specific variables 
were used to determine the difference or the consensus of ratings between two independent samples. Supplementary variables on additional leadership style would have enabled a more specific approach not only if there is a difference in self-ratings and others ratings but also if the leadership style yielded the similar effectiveness (Trivellas and Drimoussis, 2013) in intercommunication and trust level among leader and group members. A future research application could be a "meta-analysis" of the ratings and whether or how the results can be converted into a feedback tool or create situations of communication crisis among the group.

The variables used by the theories of transformational leadership and LMX may not have worked as great development tools of Self-Other Agreement; even the selection of independent samples $t$-test not worked as a powerful statistical tool such as multivariate and/or polynomial regressions test. However, the selection of the independent samples $t$-test gave us the opportunity to create an easier comparison between self-ratings and other-ratings. When giving feedback to leaders, we recommend using simple indices such as comparisons of self-ratings to the mean ratings across rater groups (Fleenor et al., 2010). Furthermore, the combination of leading models regarding suggestions of Hansbrough et al. (2014), mentioned in the theoretical development of this research, can lead to an even greater impact of reduction in difference and the improvement of accuracy in Self-Other Agreement to an active and dynamic organisation of LIS sector.

Furthermore, we examined two independent samples between leaders and employees, but it would be worthwhile for future research to examine similar samples, to discover the reasons where there was a disagreement between ratings of same samples-groups. It is quite possible to have different aspects and ratings due to different categories of demographic information. In addition, future statistical studies correlating with either positive or negative organisational outcomes may result in the development of a "best practices" tool kit that may be used by library administrators managing in a variety of library environments (Castiglione, 2006).

It might even be one of the first emerging studies to combine Self-Other Agreement with libraries and operational environments that are engaged in this sector. A more widespread methodological tool than the one used in this research (questionnaire response rate 59.47 per cent) could provide an opportunity to compare different behaviours between leaders and employees in different leadership styles than transformational leadership and LMX in LIS sector.

\section{Conclusion}

The reduced financial flexibility in all economies entails risks and threats for the construction of environments that are active and dynamic in the sector of LIS. The communication and trustworthiness have to play a more decisive role in relationships between leaders and employees. A corrected and flexible communication environment could be served as a cornerstone plus as a stimulus for a more accurate Self-Other Agreement. In any case, the importance is not a matter by any means of how to improve the accuracy of Self-Other Agreement ratings. The importance lies in how to develop a strategic communication process and mechanism for a library leader to correct or to further improve communication and trustworthiness with his team members.
Communication in libraries and information services

219 
LR

65,3

\section{References}

Alexander, E.R., Helms, M.M. and Wilkins, R.D. (1989), “The relationship between supervisory communication and subordinate performance and satisfaction among professionals", Public Personnel Management, Vol. 18 No. 4, pp. 415-429.

Ammons-Stephens, S., Cole, H.J., Jenkins-Gibbs, K., Riehle, C.F. and Weare, W.H. (2009), "Developing core leadership competencies for the library profession", Library Leadership and Management, Vol. 23 No. 2, pp. 63-74.

Amundsen, S. and Martinsen, Ø.L. (2014), "Self-other agreement in empowering leadership: relationships with leader effectiveness and subordinates' job satisfaction and turnover intention", The Leadership Quarterly, Vol. 25 No. 4, pp. 784-800.

Antonakis, J. (2012), “Transformational and charismatic leadership”, The Nature of Leadership, 2nd ed., Sage, Thousand Oaks, CA.

Antonakis, J. and Atwater, L. (2002), "Leader distance: a review and proposed theory”, Leadershit Quarterlv, Vol. 13 No. 1, pp. 673-704.

Atwater, L.E., Wang, M., Smither, J.W. and Fleenor, J.W. (2009), "Are cultural characteristics associated with the relationship between self and others' ratings of leadership?", Lournal of Applied Psychology, Vol. 94 No. 4, pp. 876-886.

Atwater, L.E. and Yammarino, F.J. (1997), "Self-other rating agreement", in Ferris, G.R. (Ed.), Research in Personnel and Human Resources Management, JAI Press, Stamford, Vol. 15, pp. 121-174.

Bass, B.M. (1990), "From transactional to transformational leadership: learning to share the vision”, Organizational Dynamics, Vol. 18 No. 3, pp. 19-31.

Bass, B.M. and Avolio, B.J. (1995), Multifactor Leadership Questionnaire for Research, Mind Garden, Menlo Park, CA.

Blake, R.R. and McCanse, A.A. (1991), Leadership Dilemmas: Grid Solutions, Gulf Publishing Company, Houston, TX.

Bono, J.E., Hooper, A.C. and Yoon, D.J. (2012), "Impact of rater personality on transformational and transactional leadership ratings", Leadershi力 Quarterlv, Vol. 23 No. 1, pp. 132-145.

Broady-Preston, J.B. and Bell, S. (2001), "Motivating mid-career LIS professionals: the Aberystwyth experience”, New Librarv World, Vol. 102 No. 10, pp. 372-381.

Broady-Preston, J.B. and Lobo, A. (2011), "Measuring the quality, value and impact of academic libraries: the role of external standards", Performance Measurement and Metrics, Vol. 12 No. 2, pp. 122-135.

Broady-Preston, J.B. and Steel, L. (2002a), "Internal marketing strategies in LIS: a strategic management perspective”, Library Management, Vol. 23 Nos 6/7, pp. 294-301.

Broady-Preston, J.B. and Steel, L. (2002b), "Employees, customers and internal marketing strategies in LIS”, Library Management, Vol. 23 Nos 8/9, pp. 384-393.

Burton, J.P., Sablynski, C.J. and Sekiguchi, T. (2008), "Linking justice, performance and citizenship via leader-member exchange", Lournal of Business and Psychology, Vol. 23 Nos 1/2, pp. $51-61$.

Castiglione, J. (2006), "Organizational learning and transformational leadership in the library environment”, Library Management, Vol. 27 Nos 4/5, pp. 289-299.

Chatzoglou, P.D., Sarigiannidis, L., Vraimaki, E. and Diamantidis, A. (2009), "Investigating Greek employees' intention to use web-based training” Computers and Education, Vol. 53 No. 3, pp. 877-889. 
Colleen, S.H.K. (2015), "The relationship between academic library department experience and perceptions of leadership skill development relevant to academic library directorship", The Journal of Academic Librarianship, Vol. 41 No. 3, pp. 246-263.

Collins, M. (2007), "Understanding the relationships between leader-member exchange (LMX), psychological empowerment, job satisfaction, and turnover intent in a limited-service restaurant environment", Doctoral dissertation, The Ohio State University, $\mathrm{OH}$.

Communication

in libraries and information services

Densereau, F., Graen, G.B. and Haga, W. (1975), “A vertical dyad linkage approach to leadership in formal organizations”, Organizational Behavior and Human Performance, Vol. 13 No. 1, pp. 46-78.

Detert, J.R. and Burris, E.R. (2007), "Leadership behavior and employee voice: is the door really open?" Academv of Management Iournal, Vol. 50 No. 4, pp. 869-884.

Dyer, K.M. (2001), Relational Leadership: The ABC's and XYZ's of Leading An Organization Come Down to How You Connect with Others Bend OR7, American Association of School Administrators, Pheonix, AZ.

Felfe, J. and Schyns, B. (2010), "Followers' personality and the perception of transformational leadership: further evidence for the similarity hypothesis", British Journal of Management, Vol. 21 No. 2, pp. 393-410.

Fitsimmons, G. (2007), "Library leadership”, The Bottom Line, Vol. 20 No. 4, pp. 172-173.

Fitsimmons, G.N. (2008), “Academic library directors in the eyes of hiring administrators: a comparison of the attributes, qualifications, and competencies desired by chief academic officers with those recommended by academic library directors", Advances in Library Administration and Organization, Vol. 26 No. 1, pp. 265-315.

Fleenor, J.W., Smither, J.W., Atwater, L.E., Braddy, P.W. and Sturm, R.E. (2010), "Self-other rating agreement in leadership: a review" The Leadership Quarterlv, Vol. 21 No. 6, pp. 1005-1034.

Gao, L., Janssen, O. and Shi, K. (2011), "Leader trust and employee voice: the moderating role of empowering leader behaviors", The Leadership Quarterly, Vol. 22 No. 4, pp. 787-798.

Graen, G.B. (1976), "Role-making processes within complex organizations", Handbook of Industrial and Organizational Psychology, Rand McNally, Chicago, IL, pp. 1202-1245.

Graen, G.B. and Uhl-Bien, M. (1991), "The transformation of professionals into self-managing and partially self-designing contributions: toward a theory of Leadership making", Journal of Management Systems, Vol. 3 No. 3, pp. 33-48.

Graen, G.B. and Uhl-Bien, M. (1995), "Relationship-based approach to leadership: development of leader-member exchange (LMX), theory of leadership over 25 years: applying a multi-level, multi-domain perspective”, Leadership Quarterly, Vol. 6 No. 2, pp. 219-247.

Hallahan, K., Holtzhausen, D., Van Ruler, B., Vercic, D. and Sriramesh, K. (2012), "Defining strategic communication" International Journal of Strategic Communication, Vol. 1 No. 1, pp. 3-35.

Hansbrough, T.K., Lord, R.G. and Schyns, B. (2014), "Reconsidering the accuracy of follower leadership ratings", The Leadership Quarterly, Vol. 26 No. 2.

Hofmann, D.A. and Morgeson, F.P. (1999), "Safety-related behavior as a social exchange: the role of perceived organizational support and leader-member exchange", Lournal of Applied Psychology, Vol. 84 No. 2, pp. 286-296. 
LR

65,3 
Trivellas, P. and Reklitis, P. (2014), "Leadership competencies profiles and managerial effectiveness in Greece", Procedia Economics and Finance, Vol. 9 No. 1, pp. 380-390.

Yammarino, F.J. and Atwater, L.E. (1993), "Understanding self-perception accuracy: implications for human resource management”, Human Resource Management, Vol. 32 Nos 2/3, pp. 231-247.

Communication in libraries and information services

Yammarino, F.J. and Atwater, L.E. (1997), "Do managers see themselves as others see them? Implications of self-other rating agreement for human resources management", Organizational Dvnamics, Vol. 25 No. 4, pp. 35-44.

\section{Corresponding author}

Ioannis C. Drivas can be contacted at: giandrivas@gmail.com

For instructions on how to order reprints of this article, please visit our website:

www.emeraldgrouppublishing.com/licensing/reprints.htm

Or contact us for further details: permissions@emeraldinsight.com 